\title{
CURRENT STATE AND POST-CRISIS DEVELOPMENTS OF EU-CIS TRADE: PERSPECTIVE TOOLS TO ENSURE SUSTAINABILITY
}

\section{Anna IVOLGA', Vasily EROKHIN ${ }^{2}$}

\author{
Stavropol State Agrarian University, Stavropol, Russian Federation' \\ Moscow University of Finance and Law, Moscow, Russian Federation ${ }^{2}$
}

\begin{abstract}
Global financial and economic recession had negatively influenced the dynamic of the international trade in 2008-2012. The post-crisis period of global market development can be described by the tendency of growing international trade flows. However, according to many experts, to ensure this tendency, the international trade policy within the frame of the WTO should be changed. The paper includes the analysis of current market of the EU-CIS trade, describes the main tendencies of its post-crisis development and major approaches and tools to ensure sustainability of such development. The analysis involved main exporting and importing countries for each analyzed product group. Sub-goals include an overview of the WTO threats and opportunities for Russian agriculture and trade with agricultural products globally, as well as comparison of main consequences of the WTO accession for the CIS countries, such as Kazakhstan, Ukraine, Kyrgyzstan, Georgia and Moldova. This is also related to the state support of agricultural production in Russia and CIS and its influence on volumes, directions, structure and effectiveness of international trade with agricultural products.
\end{abstract}

Keywords: foreign trade, European Union, Commonwealth of Independent States, economic crisis, sustainable development

\section{Introduction}

EU-CIS trade flowis one of the world's biggest trade flows. CIS is a relevantEU-27 trade partner but current processes of trade integration and globalization change the structure of the market and correct some of the trade flows. WTO influences strongly the EU-CIS trade, especially with Russian accession to WTO in 2012.

The EU and the other top exporters all benefited from WTO. Following the slump in 2009, the EU bounced back with over $20 \%$ growth in exports, in order to reach the record levels in 2010-2011. For the first time since 2006, the EU's trade balance improved to the extent that it emerged from recession as a net exporter in 2010. The $€ 6$ billion agricultural trade surplus is large due to expansion of the value of exports driven by stronger demand for final products, as the EU's key trading partners come out of recession, and higher prices for commodities and intermediate goods.

While EU-27 is recovering after the global recession, CIS countries still face many difficulties, especially unfamiliar condition of trade integration and open markets. Along with a wide range of advantages given by the WTO system to the CIS economies, many experts reasonably observe series of problems and challenges related mainly to the alleviation of access to internal markets for foreign goods, decreasing competitiveness of CIS producers, a wave of bankruptcies, increase of unemployment and decrease of living standard.

\section{Material and methods}

The objective of the paper is to analyze the current state of the EU-CIS trade of agricultural products, discover main problems of sustainable development and elaborate perspective tools to ensure sustainability. The analysis involved main exporting and importing countries for each analyzed product group. Sub-goals include an overview of the WTO threats and opportunities for CIS agriculture and trade with agricultural products globally, as well as comparison of main consequences of the WTO accession for the CIS countries, such as Kazakhstan, Ukraine, Kyrgyzstan, Georgia and Moldova.

The current state of the EU-CIS international trade is analyzed by the example of the main goods having the biggest ratio in the structure of bilateral trade turnover. Special attention is paid to the agricultural products, since agriculture is one of the most "sensitive" spheres influenced by trade integration, including trade agreements within CIS and membership of some of the CIS countries in the WTO. The period of the analysis was 2001-2011. The analysis involved main exporting and importing countries for all the analyzed goods.

In the analysis, methods of quantitative and comparative analysis were implemented. The data summarized for the four CIS countries were compared to the EU-27 data. Trade data for this research are from Final Report "International trade and international cargo flows in 2011" by VLANT consulting company. An alternative source is the "Commodity trade between EU-27 and CIS countries, 2000-2010" by Eurostat.

\section{Results and discussion}

During the post-crisis in 2009-2011, the international trade was developing multi-directionally. In consequence of significant growth of the global prices for raw goods, the increase of global trade monetary value was 19\% in 2011. It is lower than 2010 (22\%) when international trade experienced active volume recoveries after economic crisis of the years 2008-2009. However, such a significant growth should be primarily explained by the growth of the global prices - as the quantum index of international trade in 2011 increased only by $5 \%$ (14\% in 2010). This was substantially lower than the pre-crisis levels when the sustainable growth of international economics volumes was observed - up to $10 \%$ annually during the preceding decade.

The indicative trend of the post-crisis international economic development is the advanced growth of interregional trade, observed in 2006-2011 even despite the economic recession. This shows the strengthening differentiation of labour on macroeconomic level. The highest increase of exports was observed for the regions specialized in raw goods supplies. The best imports dynamics was observed in the developing countries (as a result of global imports appreciation) and again, the same "raw" regions - as a result of growth of their revenues on global market and enlargement of their effective demand.

EU-CIS trade flow remained one of the world's biggest trade flows in 2009-2011, although South-East Asia - East Asia trade flow, the 
most dynamic one in the last decade, was progressively reaching its levels. Commonwealth of Independent States is the relevant EU-27 trade partner. The annual volume of interregional trade almost tripled - from $€ 109.7$ billion in 2000 to $€ 330.0$ billion in 2011. However, the significant drop of exports and imports in 2009 has to be noticed as a result of global economic recession.

Following the rapid growth (up to $30 \%$ annually) of interregional trade volumes in 20092011 let us forecast the recovery of exports and imports volumes as of 2008 level even in 2012, as well as the achievement of horizon of $€ 250$ billion imports and $€ 170$ billion exports in 2013. In 2001-2011 (except of the "crisis" in 2008-2009), the annual increase of the EU-27 imports from the CIS countries was $10.1 \%$. Such a high level can be explained primarily by the growth of imports volume from Russia as well as imports increase from Kazakhstan, Azerbaijan and Ukraine.

Russian share in the structure of foreign trade turnover between the EU-27 and the CIS countries remains significant, including the period of global economic recession and considering the WTO non-membership status of Russia until 2012. Russian share is $79 \%$ of the EU-27 imports from the CIS countries and $71 \%$ of the EU-27 exports to the CIS countries. Structure of Russian export to the EU is homogenous during last decades over 78\% Russian exports to EU-27 is mineral fuel (2011). EU-27 exports to Russia are much more diversified, mainly consisting of machineries, equipments and transport vehicles (44\% in 2011).

During the same period of 2001-2011, the annual average increase of the EU-27 exports to the CIS countries was $13.9 \%$. The given increase was provided primarily by the growth of the exports to Russia, Ukraine, Belarus and Kazakhstan.

Incomplete recovery of the European demand for the CIS raw goods (especially fuel), caused by the financial and economic difficulties and growth of international competition on the European market, until now prevents the recovery of "EU-27-CIS" trade flow volumes up to the pre-crisis levels. The highest growth rates can be observed for grain and coal sectors. The significant increase in noticed for non-metallic mineral raw materials and other fuels. However, with the general increasing trend, some of the commodity groups, such as pipeline gas, oil and iron ore, demonstrated the negative dynamics.

After the collapse of the USSR, the CIS countries have been developing multidirectionally but in general, they were primarily oriented to European Union as the largest market for their products. A lot of partnership

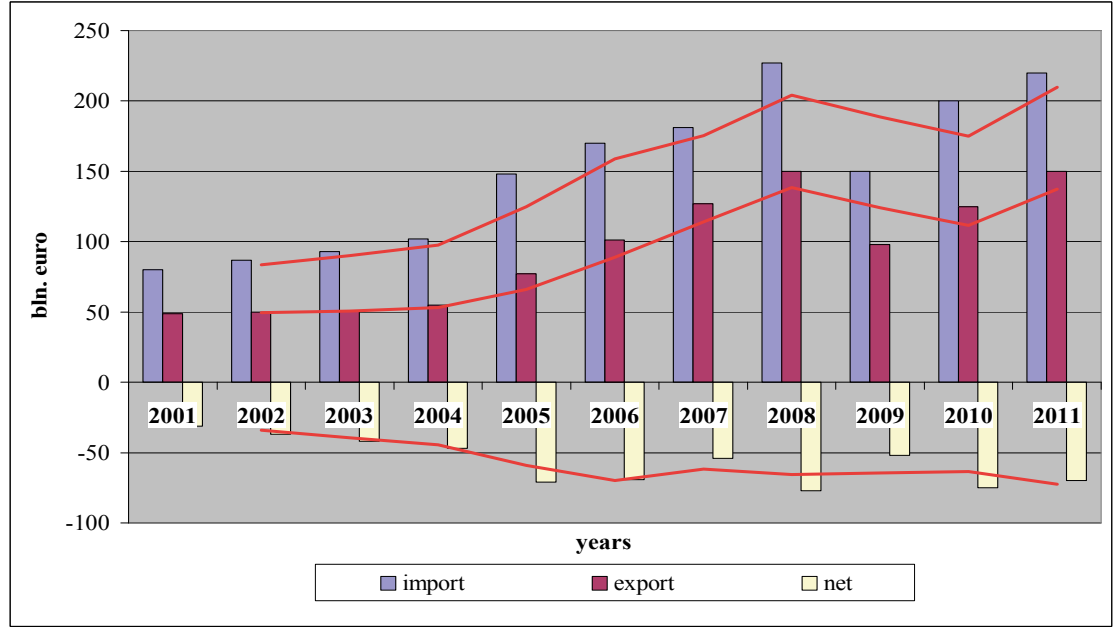

Figure 1 Interregional EU-27-CIS trade in 2001-2011 in billion $€$

Source: International trade and international cargo flows in 2011 (final report), Consulting company VLANT, 2012, access at http://vlant-consult.ru

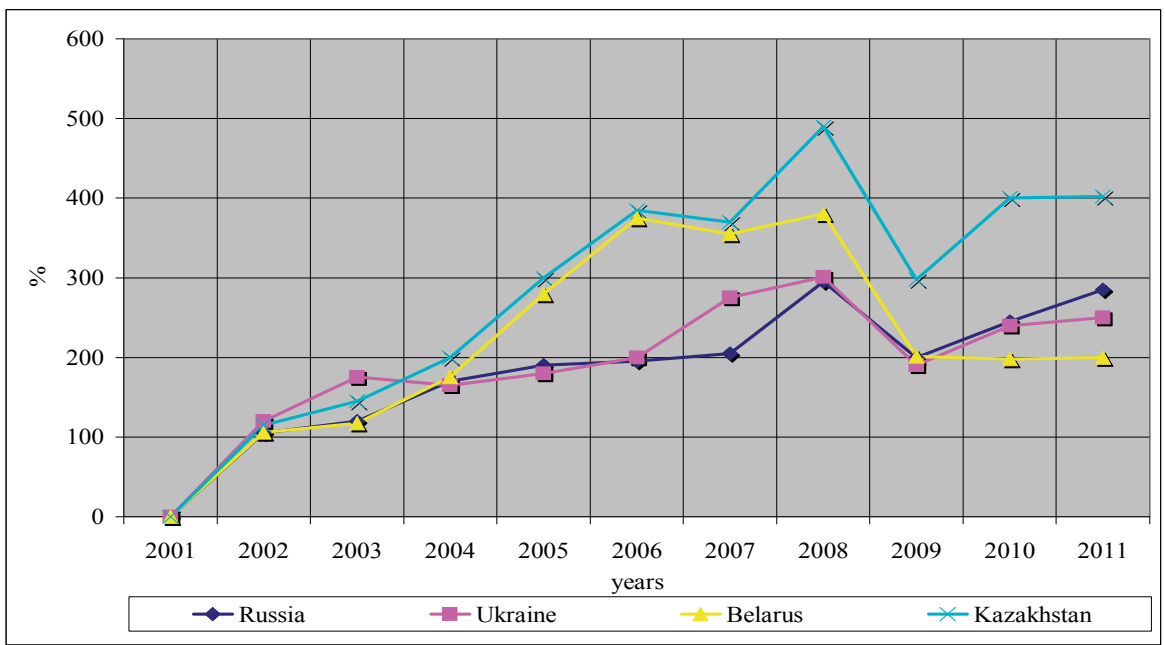

Figure 2 Dynamics of the EU-27 imports from some of the CIS countries in 2001-2011 in \% Source: Nilson, 2011. Commodity trade between EU-27 and CIS countries, 2000-2010, Eurostat, Statistics in focus, Vol. 40, access at http://epp.eurostat.ec.europa.eu

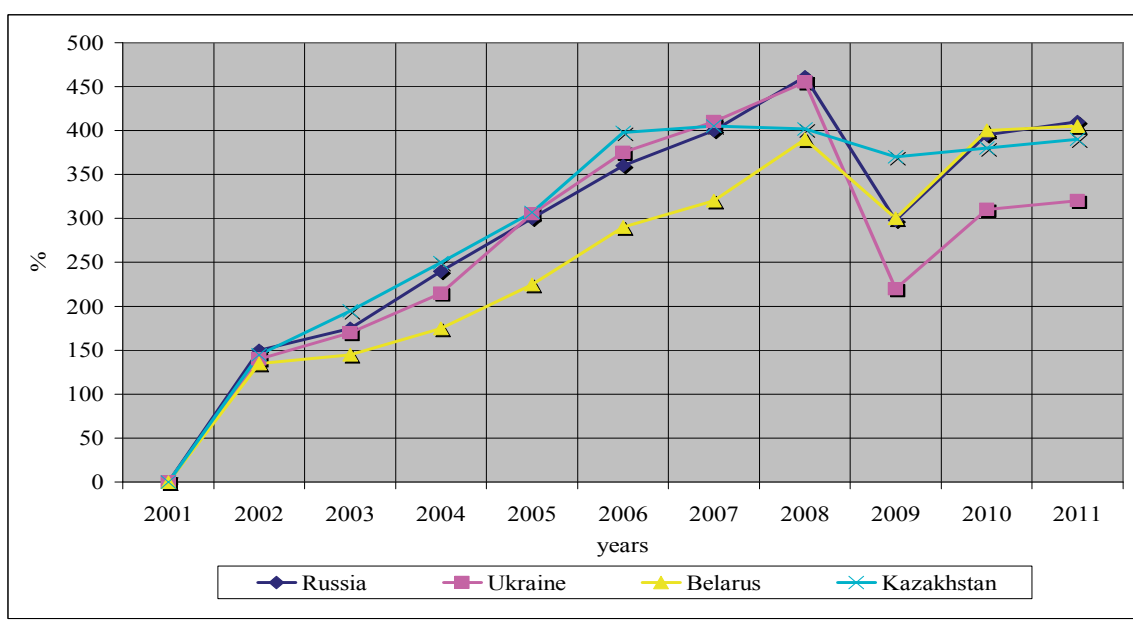

Figure 3 Dynamics of the EU-27 exports to some of the CIS countries in 2001-2011 in \% Source: Nilson, 2011. Commodity trade between EU-27 and CIS countries, 2000-2010, Eurostat, Statistics in focus, Vol. 40, access at http://epp.eurostat.ec.europa.eu 


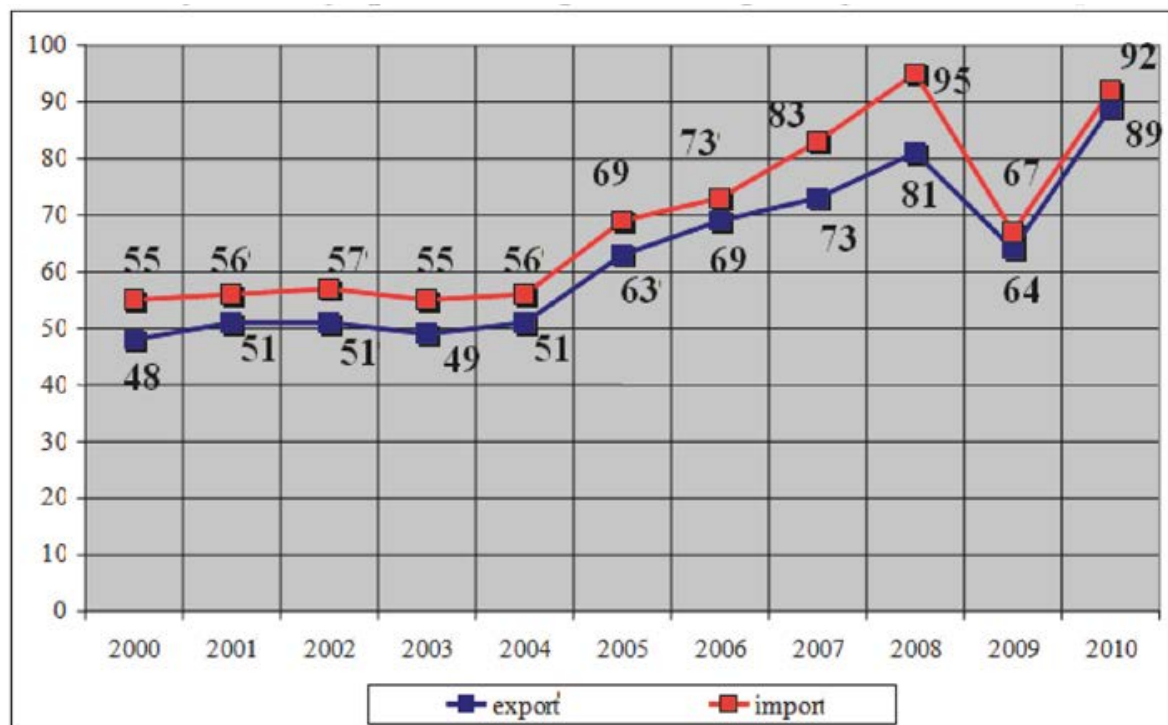

Figure 4 Dynamics of the agricultural exports and imports of the EU-27 in billion $€$

Source: International trade and international cargo flows in 2011 (final report), Consulting company VLANT, 2012, access at http://vlant-consult.ru

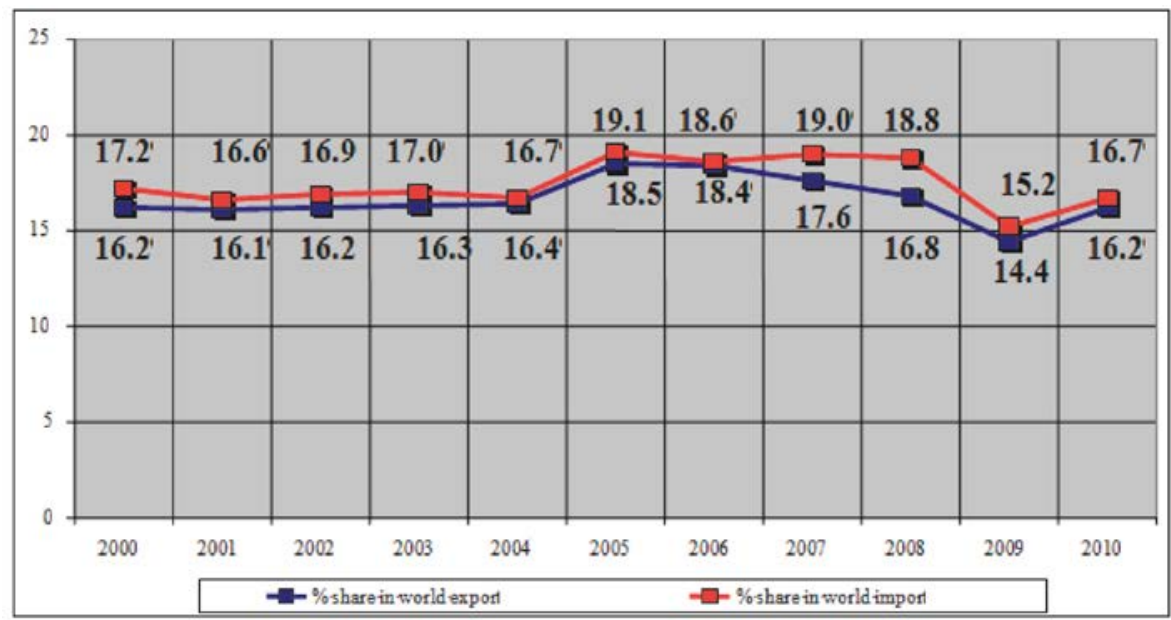

Figure 5 Dynamics of the share of the EU-27 in world agricultural trade in \%

Source: International trade and international cargo flows in 2011 (final report), Consulting company VLANT, 2012, access at http://vlant-consult.ru

trade agreements between $\mathrm{CIS}$ and EU countries had been concluded during 2001-2011. At the moment, the EU Commission actively supports its partners in trade development, for example through the partnership and collaboration agreements. Most of the Central Asia countries within the CIS are the beneficiaries of the Global System of Preferences (trade) of the EU27 countries, as well as active participants of integration in the frameworks of World Trade Organization (WTO).

The WTO membership experience of Kazakhstan can be recognized as one of the most successful among other CIS countries. Kazakhstan is one of the biggest Russian trade partners in the CIS, which is why the study of its experience can be very valuable. According to the World Bank data, investments to agriculture in Kazakhstan are on the second place after the oil production according to their effectiveness. The reforms in Kazakhstan started right in the period of the WTO accession. The state provides the following privileges to stimulate the development of domestic agricultural production and food processing: cheapening of combustibles and lubricants, lowering of interest rates on credits in the second level banks, leasing for special machinery and processing equipment. Purchasing of seeds is subsidized on $40 \%$ and their production reaches from $40 \%$ to $100 \%$. The government supports the projects related to fruit trees growing, production of mineral fertilizers and development of purestrain stock breeding. The volume of state support of agriculture has grown five times since 2002 and has reached $\$ 924$ million, including $\$ 146$ million for subsidies and $\$ 355$ million for credit programs.
Related institutions have been also established, such as ISC "KazAgro", JSC "KazAgroFinance" or ISC "Fund of financial support for agriculture".

It is also necessary to investigate the WTO membership experience of another big postsoviet economics, Ukraine. The main problem in Ukraine is how to support the domestic agricultural producers. Liberalization of the trade regime has caused the active interpenetration of the domestic Ukrainian food market with imported agricultural and food products. Since the WTO accession, the growth of import volume of agricultural product has reached $11 \%$. The growth of import volume was caused by import deliveries of meat $(43 \%$ in the structure of increase). Volumes of meat deliveries have grown up to 6.5 times. It is especially necessary to distinguish the growth of import deliveries of grain and sugar, which are traditional domestic products in Ukraine.

In 2009, Ukraine introduced extra custom duties to support the national payment balance (13\% for 63 goods, including meat, fish and alcohol). As long as such measure contradicts the WTO rules, the Government of Ukraine has shortened this list leaving only industrial products (automobiles and refrigerators). The volume of state support of agriculture decreased twice in 2010 and the budget financing was stopped for seven budget programs.

In 2009, the Decree of the Ukrainian President "About report of the Government about the results of WTO membership" was accepted. The document contains measures and trade procedures aimed to protect domestic producers on the domestic market from dumping and subsidized import, as well as activities to stimulate the increase of domestic goods supply on the domestic market.

The excessive liberalization and openness of the Ukrainian domestic market are testified by the data on the GDP structure. During 2000-2004, the total export and import steady exceeded 100\% (export exceeded import). Since 2006, the opposite picture has been observed: import exceeded export, i.e. the national economics had transferred to the import-dependent model of foreign trade relations.

Accordingly, the macroeconomic consequences of the WTO accession for Ukraine testify that the membership in this international organization has not brought the expected positive results in economics. Because of the high dependency on the external trade, agriculture turned out to be exceedingly exposed to the influence of the negative factors of the global crisis. 
During 2005-2011, import volume of vegetables and fruits to Ukraine sharply increased ( $\$ 860$ million, growth by 4.2 times comparing to 2005). The quantity of fruits and vegetables import increased to $77 \%$. It is especially important to note the growth of import of agricultural products traditionally produced in Ukraine. In 2005-2011, the import of potatoes, cabbage, onion, carrot, tomatoes and cucumbers increased 18.5 times (up to 190 thousand tons) and the import of apples, pears, cherries and apricots increased almost five times (up to 210 thousand tons). Since January 2011, Ukraine (according to the undertaken WTO obligations) finagled the import duties on alcohol beverages. Consequently, the domestic production of grape wine decreased to $41.3 \%$. Import volume of swine meat increased 2.9 times, the import share of this product on the domestic market reached $40 \%$.

Thus, during three years of the WTO membership, Ukraine lost more than it gained. This should the subject of initiation of negotiations on correction of the WTO obligations for Ukraine.

Kyrgyzstan's experience of the WTO membership can be recognized as one of the most negative. Kyrgyzstan officially entered WTO on December $20^{\text {th }}, 1998$. The negotiations lasted about 2.5 years. The first thing attracting attention is the precipitation of Kyrgyzstan's entry. According to experts' estimates, until now, such a rapid entry to this organization remains the single precedent of such kind. It has caused the negative consequences because of the insufficient working out of the accession obligations. For example, Kyrgyzstan has not preconditioned the status of the developing country, thereby losing the related preferences.

Establishing equal conditions for domestic and foreign products on the national market became one of the most negative consequences for Kyrgyzstan. This negatively redounded upon the domestic industry in the period of reconstruction. International experience shows the strict dilemma for such countries as Kyrgyzstan - "goods or investments". Kyrgyzstan's accession to the WTO closed the domestic market for investments and opened it for imported products. This led to the growing raw-material orientation of the Kyrgyzstan's economic and prolonged recession in its various sectors, including agriculture (which share in the national economic is 80\%). Entering WT0, Kyrgyzstan was obliged to cancel export subsidies for domestic agricultural production, to refuse to implement licensing and quoting of agricultural import and to charge import products with no more than $10 \%$ custom fee. Eventually Kyrgyzstan, despite the quite long membership in WTO, has one of the worst economic indicators throughout the CIS.

Georgia entered WTO a little bit later than Kyrgyzstan (in 2000), more because of the political reasons than the economic necessity. Such haste when Georgia accepted the offered obligations led to the difficulties at completion of the undertaken obligations. For example, the sector initiatives in agriculture were not implemented because of the contradictions with International Monetary Fund (IMF) and the special custom tariffs for agricultural raw materials and machinery were not introduced.

For Moldova, the process of WTO accession became longer than for Georgia and Kyrgyzstan (8 years of negotiations, accession in 2001). However, this long period can be explained by the absence of the clear economic policy of the Government of Moldova and not detailed working out of the accession conditions. The state support of agriculture, which is the main branch of Moldova economics, became one the most difficult. Moldova was able to defend the necessity of subsidies for agriculture but undertook the obligation to shorten the volume of support on $16 \%$ during four years.

During the first years after Moldova's accession to WTO, the situation in agriculture worsened: growth rates slowed, the production volume decreased to $14 \%$. Since 2005 , the situation has become steadier and the annual growth reached 1-2\%. Entering WT0, Moldova planned to get a wider access to the global market of agricultural production, especially for its main export product, alcoholic beverages. These expectations became largely true. The export volume increased in two times since the WTO accession, especially to the countries beyond CIS. Processed food products became the main part of the import volume.

Membership of some of the CIS countries in WTO and recent Russian accession to this global trade system can change the structure and main tendencies of the EU-CIS trade significantly. This is especially related to the EU-CIS trade with agricultural products, since agriculture is supposed to be one of the most "sensitive" spheres influenced by trade agreements within CIS and Russian accession to WTO.

In 2010, the world trade of agricultural products increased by $12 \%$ compared to 2008, reaching the record height. EU-27 stood as the largest importer of agricultural products in the world. Increased trade in agriculture was due to the increased product demand from major emerging economies compared to previous years. World agricultural trade reached an all-time height, at least $12 \%$ (expressed in euro) above the previous record set in 2008. The impact of the economic crisis led to a contraction of $6 \%$ in global agricultural exports in 2009 but they rebounded by $20 \%$ in 2010 (figure 4).

The EU as well as the other top exporters all benefited from buoyant markets. Following the slump in 2009, the EU, the USA and Brazil bounced back with over $20 \%$ growth in exports, to reach record levels in 2010. The EU's trade balance improved to the extent that it emerged from recession as a net exporter in 2010, for the first time since 2006. The $€ 6$ billion agricultural trade surplus is large due to the expansion in the value of exports, driven by stronger demand for final products, as the EU's key trading partners come out of recession, as well as higher prices for commodities and intermediate goods.

The EU remains by far the world's biggest importer with imports worth $€ 83$ billion in 2008-2010, well ahead of the USA. The EU imports grew by $9 \%$ in 2010, though they remain $5 \%$ below the peak of 2008, when they reached $€ 88$ billion. This is a result of the sharp drop of over 12\% in 2009 after two years of very strong growth of over $13 \%$ per year. The EU's share of the global imports was over $19 \%$ in 2009 . US imports grew strongly by $17 \%$ in 2010 , having suffered a less severe decline (just 5\%) than the EU in 2009.

The EU trade balance continued to improve in 2010 to the extent that it switched from being a net importer with a trade deficit of $€ 2.5$ billion in 2009 to a net exporter, for the first time since 2006, with an agricultural trade surplus of over $€ 6$ billion. The surplus is large due to the growth in the value of exports after the contraction of trade in 2009 linked to economic crisis and the drop in commodity prices. The EU and the other top exporters all benefited from buoyant export sales. The EU export profile has changed little in recent years. Final products and other products account together for $69 \%$ of the value of the EU exports in 2008-10, while intermediate products and commodities represent $20 \%$ and $9 \%$ respectively.

\section{Conclusions}

In the mid-term, the structure of the EU-27-CIS foreign trade turnover will not change significantly. The CIS-EU trade flow will primarily consist of raw commodities. Its largest constituent will remain oil. There will be also relevant (but not comparable to oil in their sizes) shares of pipeline gas, coal, petrochemicals and iron ore. CIS deliveries will be mainly formed by Russia. Ukraine and Kazakhstan will also become big suppliers. The main CIS importer among the EU-27 countries will be Germany, followed by Italy. The Netherlands and Poland will increase their shares in the EU-27 imports from the CIS countries. 
Export of agricultural products from the EU-27 to the CIS countries will grow in the mid-term. The growth will be caused by a number of reasons, particularly: continuing liberalization of interregional trade within CIS, as well as a result of multilateral EU-CIS agreements; Russia, which is the largest economy of the region, accessed to the WTO; low competitiveness of the CIS domestic agricultural producers comparing to the EU and the US farmers, supported by their governments (especially in food production and high-level food processing where added value is the largest); incomparably lower volumes of the state support for domestic agricultural producers not only in the CIS countries but even in Russia, which does not provide sufficient protection of interregional market and do not allow to develop effectively high-quality food processing and food production in CIS-countries.

WTO and the trade liberalization obviously bring a set of opportunities for an accessing country. WTO is based on an equality of rights and obligations. This means that $\mathrm{EU}$ countries are obliged to open their domestic markets for the CIS agricultural and food products. However, most of the CIS-countries, including Russia, cannot fully benefit from these opening opportunities. The state is not able to support the massive expansion of domestic farmers to the European markets. Transition period can take long time. If CIS and Russia do not use new opportunities today, better times may not come at all.

\section{References}

DIAZ-BONILLA, E. - RECA, L. 2000. Trade and agro-industrialization in developing countries, Mimeo, IFPRI Trade and Macroeconomics, Washington, DC.

EROKHIN, V. 2010. Russian accession into WTO: new challenges for agriculture. Russian entrepreneurship, vol. 12, 2010, no. 1, p. 11-16.

EROKHIN, V. - IVOLGA, A. 2011. Entrepreneurship in agriculture: new challenges of international trade integration. Contemporary Agriculture: the Serbian Journal of Agricultural Sciences, vol. 60, 2011, no. 3-4, p. 398-402.

Erokhin, V. - Ivolga, A. 2012. International Trade with Agricultural Products: Influence of Market Globalization and Intergration, p. 61-84, In: Horska, Elena: Food Sciences and Business Studies, Nitra : Slovak University of Agriculture in Nitra, 2012. ISBN 978-80552-0815-2
EROKHIN, V. - IVOLGA, A. 2011. Regional aspects of trade integration: perspectives of development of entrepreneurship in agriculture, Proceedings, Conference Sustainable agriculture and rural development in terms of the Republic of Serbia strategic goals implementation within Danube region - development of the local communities, Institute of Agricultural Economics, Belgrade, 2011, p. 270-275.

EROKHIN, V. - IVOLGA, A. 2011. Russian accession into WTO: overview of the undertaken obligations, Management of economic systems: electronic scientific magazine, vol. 12(36), Retrieved December 22, 2011, access at http://uecs.ru.

EROKHIN, V. - IVOLGA, A. 2012. Russia's WTO accession: a new driver for sustainable economic development of EU, Proceedings, International Scientific Conference Business in the EU and in the world, Slovak University of Agriculture, Nitra, Slovak Republic.

EROKHIN, V. - IVOLGA, A. 2011. WTO: how the trade integration may effect on business, Quality of entrepreneurship environment, Nitra : SUA, 2011, p. 24-29.

INTERNATIONAL TRADE and international cargo flows in 2011 (final report), Consulting company VLANT, 2012, access at http://vlant-consult.ru

JOSLING, T. - ANDERSON, K. - SCHMITZ, A. - TANGERMAN, S. 2010. Understanding International Trade in Agricultural Products, One Hundred Years of Contributions by Agricultural Economists, Am. J. Agr. Econ., vol. 92, 2010, no. 2, p. 424-446.

LIAPIS, P. 2011. Changing Patterns of Trade in Processed Agricultural Products, OECD Food, Agriculture and Fisheries Papers, no. 47, OECD Publishing.

NILSON, A. 2011. Commodity trade between EU-27 and CIS countries, 2000-2010, Eurostat, Statistics in focus, vol. 40, access at http://epp.eurostat.ec.europa.eu.

\section{Contact address:}

Anna Ivolga, PhD, Faculty of Social and Cultural Service and Tourism, Stavropol State Agrarian University, 12, Zootekhnichesky Pereulok, Stavropol, Russian Federation, phone: +7-8652-355980, e-mail:annya_iv@mail.ru

Vasily Erokhin, PhD, Faculty of Master Business Administration, Moscow University of Finance and Law MFUA, 8 build. 1, Presnenskaya Embankment, Moscow, Russian Federation, phone: +7-499-995-19-63, e-mail: basilic@list.ru 